Methodology article

\title{
Specific and sensitive detection of the conifer pathogen Gremmeniella abietina by nested PCR Qing-Yin Zeng ${ }^{1,2}$, Per Hansson ${ }^{3}$ and Xiao-Ru Wang*1
}

Address: ${ }^{1}$ National Institute for Working Life, SE-90713 Umeå, Sweden, ${ }^{2}$ Department of Molecular Biology, Umeå University, SE-90187 Umeå, Sweden and ${ }^{3}$ Department of Silviculture, the Swedish University of Agricultural Sciences, SE-90183 Umeå, Sweden

Email: Qing-Yin Zeng - qingyin.zeng@molbiol.umu.se; Per Hansson - Per.Hansson@ssko.slu.se; Xiao-Ru Wang* - xiao-ru.wang@niwl.se

* Corresponding author

Published: 09 November 2005

BMC Microbiology 2005, 5:65 doi:10.1 |86/147|-2180-5-65

This article is available from: http://www.biomedcentral.com/I47I-2/80/5/65

(c) 2005 Zeng et al; licensee BioMed Central Ltd.

This is an Open Access article distributed under the terms of the Creative Commons Attribution License (http://creativecommons.org/licenses/by/2.0), which permits unrestricted use, distribution, and reproduction in any medium, provided the original work is properly cited.
Received: 28 June 2005

Accepted: 09 November 2005

\begin{abstract}
Background: Gremmeniella abietina (Lagerb.) Morelet is an ascomycete fungus that causes stem canker and shoot dieback in many conifer species. The fungus is widespread and causes severe damage to forest plantations in Europe, North America and Asia. To facilitate early diagnosis and improve measures to control the spread of the disease, rapid, specific and sensitive detection methods for $G$. abietina in conifer hosts are needed.

Results: We designed two pairs of specific primers for $G$. abietina based on the I8S rDNA sequence variation pattern. These primers were validated against a wide range of fungi and I4 potential conifer hosts. Based on these specific primers, two nested PCR systems were developed. The first system employed universal fungal primers to enrich the fungal DNA targets in the first round, followed by a second round selective amplification of the pathogen. The other system employed G. abietina-specific primers in both PCR steps. Both approaches can detect the presence of $G$. abietina in composite samples with high sensitivity, as little as $7.5 \mathrm{fg} G$. abietina DNA in the host genomic background.

Conclusion: The methods described here are rapid and can be applied directly to a wide range of conifer species, without the need for fungal isolation and cultivation. Therefore, it represents a promising alternative to disease inspection in forest nurseries, plantations and quarantine control facilities.
\end{abstract}

\section{Background}

Gremmeniella abietina (Lagerb.) Morelet is among the most destructive conifer forest pathogens in the northern hemisphere. This ascomycete fungus has a broad host range and causes stem canker and shoot dieback in many conifer species of the genera Pinus, Abies, Picea, Larix, Tsuga and Pseudotsuga [1-3]. In Sweden, G. abietina is found on the two native conifers Picea abies and Pinus sylvestris, as well as the introduced species, Pinus contorta [4-6].
Under favorable conditions, the life cycle of G. abietina takes two years to complete [5]. The fungus may grow in the host as an endophyte for more than one year $[7,8]$, and infected trees can remain undetected for several years before manifesting visible symptoms. This poses difficulties for diagnosing disease at an early stage, using asymptomatic materials. Nursery seedling inspection and quarantine control require sensitive detection methods to limit the spread of the pathogen. Various morphological, physiological, pathogenic and biochemical characters and 


\begin{tabular}{|c|c|c|}
\hline \multicolumn{3}{|c|}{ Gremmeniella abietina $18 \mathrm{~S}$ rDNA } \\
\hline & $\overline{\text { NS.Grem6 }}$ & $\overline{\text { NS.Grem4 }}$ \\
\hline Primer & \multicolumn{2}{|l|}{ Sequence (5'-3') } \\
\hline NS1 & \multicolumn{2}{|l|}{ GTAGTCATATGCTTGTCTC } \\
\hline NS8 & \\
\hline NS.Grem3 & & \\
\hline NS.Grem4 & $\begin{array}{l}\text { AACCITGAACT'TGGTTGGTT } \\
\text { TGGTGGAGTGTTGCCACT }\end{array}$ & \\
\hline NS. Grem5 & \multicolumn{2}{|l|}{ CACTGATCCGACCGGGT } \\
\hline NS.Grem6 & \multicolumn{2}{|l|}{ CCTTTCGGACAAGGAAGG } \\
\hline
\end{tabular}

\section{Figure I}

Location and sequences of the primers used in this study.

molecular markers have been employed to distinguish and characterize different races and types of the fungus, such as the North American race (NA), European (EU) race, and large tree type (LTT) and small tree type (STT) [915]. Most of these methods require isolation of the fungus in culture. This process is time consuming and is not appropriate for the detection of the fungus directly in infected but asymptomatic tissues.

Specific polymerase chain reaction (PCR) based detection methods are sensitive and robust techniques when used in plant disease diagnostic research. By employing specific PCR primers it is possible to selectively amplify the pathogen from infected tissues without the need for isolation. Among the different PCR techniques, nested PCR (a twostep PCR system in which the first round PCR products are subjected to a second round PCR amplification with more specific primers) is extremely sensitive and allows the detection of a fungal pathogen in minute amounts of infected material [16-18]. Recently, a nested PCR procedure was developed for the detection of G. abietina [19]. This method is based on the polymorphic sites in the ribosomal DNA (rDNA) internal transcribed spacer (ITS). The ITS evolves rapidly and significant variations within a species or even within a genome have been reported for fungi and plants [20-23]. The specific markers from the ITS region are, therefore, potentially unstable because of the high mutation rate, and would need to be validated by extensive sample testing. The 18S rRNA gene is much more conservative compared to the ITS. Specific markers developed from this DNA region are less likely to be invalid due to intraspecific variations producing false negative detections.

The aim of the present study was to develop a stable, specific and sensitive method for detecting G. abietina infection in a broad range of hosts. There was no intention to differentiate between the races/types of the fungus, which would be difficult using this conserved DNA segment. The $18 \mathrm{~S}$ rRNA gene was sequenced from G. abietina isolated

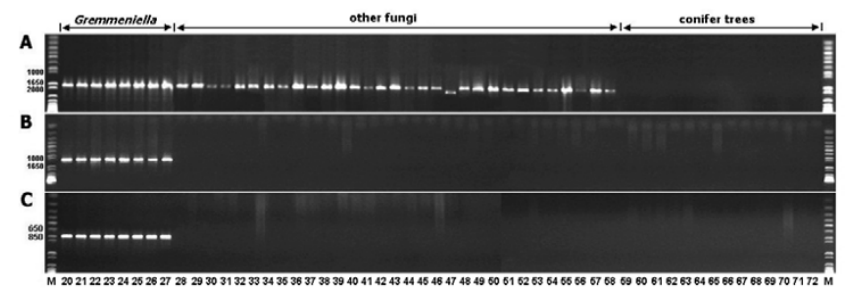

Figure 2

Specificity test of different PCR assays. A, amplification using fungal universal primer pair NSI/8; B and C, amplification using specific primer pairs NS.Grem3/4 and NS.Grem5/6, respectively. $G$. abietina isolates $I-19$ were not shown on this gel due to space limitation. Nested PCR using NS.Grem3/4 and NS.Grem5/6 as inner primers gave amplification patterns identical to $B$ and $C$, respectively. Fungal strains in each lane are in the order given in Table I and 2. M: I kb Plus DNA Ladder (Invitrogen).

from four host species. Highly specific primers were designed for G. abietina, based on extensive sequence homology analysis. Two nested PCR systems were developed for sensitive detection of the pathogen in host tissues. The first system employed fungal universal primers in the first round PCR, to enrich the fungal rDNA in the plant genomic background, followed by the specific amplification of G. abietina rDNA in the second round PCR. The second system employed G. abietina specific primers in both PCR rounds. Both approaches can detect the presence of G. abietina in composite samples with high sensitivity. This procedure is rapid and can be used directly on plant materials without the need for fungal isolation and subsequent cultivation. The methods described here represent a promising alternative to disease inspection in forest nurseries, plantations and quarantine control facilities.

\section{Results}

\section{Specific amplification of G. abietina}

The fungal universal primer pair NS1/8 gave an amplification product of about $1700 \mathrm{bp}$ for all of the 58 fungal strains tested, except Stachybotrys bisbyi which produced a larger PCR fragment (Fig. 2A). None of the 14 conifer species produced any amplicon with this primer pair, demonstrating the incompatibility of the primers to conifer $18 \mathrm{~S}$ rDNA. The two pairs of specific primers, NS.Grem3/4 and NS.Grem5/6, amplified fragments of $1080 \mathrm{bp}$ and $837 \mathrm{bp}$, respectively, only in G. abietina (Fig. $2 \mathrm{~B}, \mathrm{C}$ ). No amplified products were generated from samples of any of the other fungi and plants with these two primer pairs. When used as inner primers in nested PCR, in combination with NS1/8 as outer primers, NS.Grem3/ 4 and NS.Grem5/6 gave amplification patterns identical to those in corresponding single-step PCR assays. The nested PCR using NS.Grem3/4 as outer primers and 


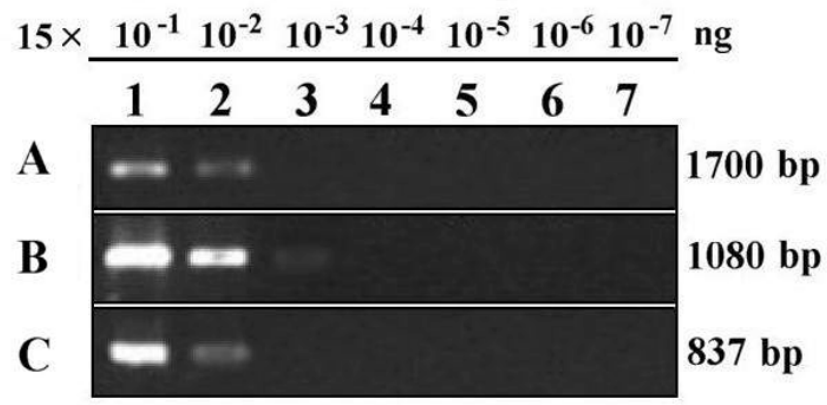

Figure 3

Comparison of detection sensitivity between single-step PCR assays. A, universal primers NSI/8; B, specific primers NS.Grem3/4; C, specific primers NS.Grem5/6. A I0-fold dilution series of $G$. abietina was used as the template.

NS.Grem5/6 as inner primers gave an amplification pattern identical to that of NS.Grem5/6. No amplifications were observed for any of the plants and fungi except for $G$. abietina by any of the nested PCR (amplification pattern identical to Fig. 2B, C, thus not shown). These tests were performed in 3 - 5 replicates and the same specific amplification pattern was observed. The only difference between the nested PCR and the single-step specific PCR was that the amplification signals were stronger for the nested PCR. Thus, the prime pairs NS.Grem3/4 and NS.Grem 5/ 6 are highly specific to $G$. abietina at annealing temperatures of $60^{\circ} \mathrm{C}$ and $56^{\circ} \mathrm{C}$, respectively, both in single-step specific PCR and in two-step nested PCR. The lack of cross-amplification from any of the conifer species in either of the PCR systems demonstrates the scope for specific detection of the pathogen in all these hosts.

\section{Evaluation of detection sensitivity}

If the method is to be used for the early detection of infection in bulked samples in forest practice, a high level of sensitivity is required. Three different tests using a dilution series of G. abietina genomic DNA, with and without other background DNA, were conducted to compare the detection limits of the different PCR setups. The lowest DNA dilution that could provide a reproducible, unambiguous visible signal (in $3 \mu$ l PCR product) on ethidium bromide stained gels after electrophoresis was defined as the PCR detection limit.

Both the universal primers and the specific primers were tested first in single-step PCR assays. As shown in Fig. 3, all three pairs of primers can detect $0.15 \mathrm{ng}$ DNA template. Among the three primer pairs, NS.Grem3/4 gave the strongest amplification signal indicating greater PCR efficiency than the other two. Nevertheless, the magnitude of detection sensitivity was the same for all three single-step PCR systems. By combining NS1/8 amplification with a

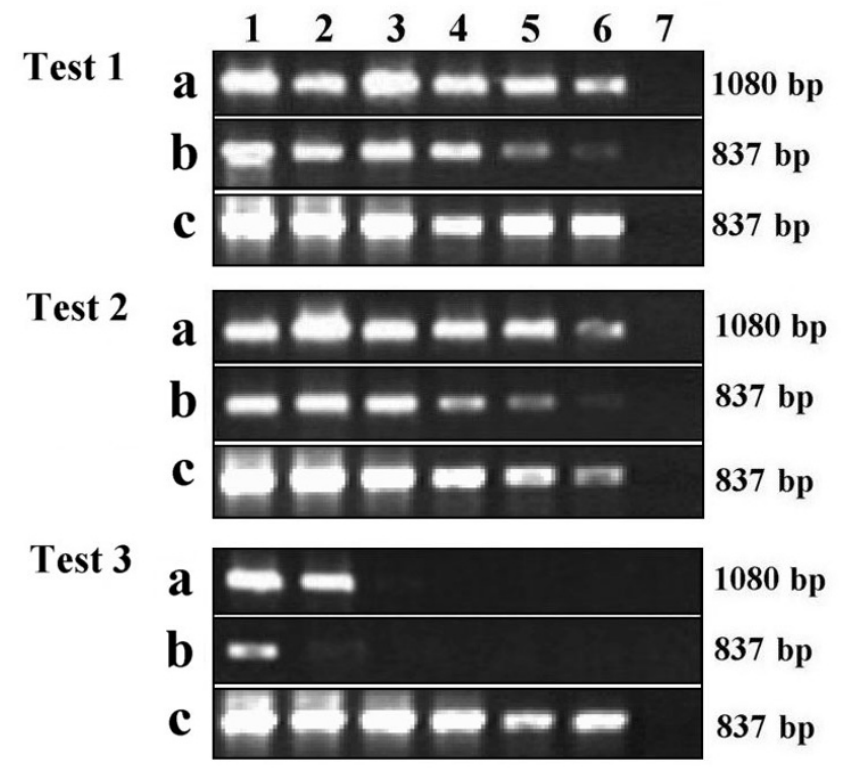

Figure 4

Comparison of the detection sensitivity between different nested PCR setups. Test I, G. abietina; Test 2, G. abietina mixed with $P$. contorta; Test $3, G$. abietina mixed with seven other fungi, in amplifications with NSI/8-NS.Grem3/4 (a), NSI/8-NS.Grem5/6 (b) and NS.Grem3/4-NS.Grem5/6 (c). See Table 3 for DNA contents in each lane.

second round amplification using either of the specific primer pairs in a nested PCR, the detection sensitivity dramatically increased. As little as $15 \mathrm{fg}$ G. abietina DNA can be detected, approximately equivalent to a single fungal genome (Fig. 4a, b Test 1). The nested PCR using NS.Grem3/4 followed by NS.Grem5/6 gave a detection sensitivity similar to the two NS1/8-based methods though with even stronger amplification signal (Fig. 4c Test 1). Thus, the nested PCR is about 10,000 times more sensitive than the single step PCR assays.

To simulate the detection of $G$. abietina in a host's genomic background, the dilution series of G. abietina DNA was mixed with $P$. contorta DNA in equal volume and subjected to nested PCR analysis (Test 2, Table 2). The amplification resulted in a detection limit of $7.5 \mathrm{fg} \mathrm{G}$. abietina DNA in the background of 6 ng of P. contorta DNA (i.e. a millionth of the quantity of host DNA, Fig. 4 Test 2 ). This test was performed in $3-5$ replicates and the same magnitude of detection sensitivity was observed. This result is very similar to the detection limit achieved with G. abietina DNA alone (Fig. 4 Test 1). Thus, the presence of $P$. contorta DNA, even at very high relative concentrations, did not affect the efficiency of the nested PCR for detecting G. abietina. 
Table I: Gremmeniella abietina isolates examined in this study.

\begin{tabular}{|c|c|c|c|c|c|}
\hline & Isolate & Sequenced & Strain type & Pine host & Origin \\
\hline I & G. abietina ALI 53I & & EU, LTT & P. contorta & Vindeln, Sweden \\
\hline 2 & G. abietina ALI 532 & & EU, LTT & P. contorta & Vindeln, Sweden \\
\hline 3 & G. abietina ALI 533 & & EU, LTT & P. contorta & Vindeln, Sweden \\
\hline 4 & G. abietina ALI 534 & & EU, LTT & P. contorta & Vindeln, Sweden \\
\hline 5 & G. abietina ALI 569 & DQ084550 & EU, STT & P. sylvestris & Arctic circle, Finland \\
\hline 6 & G. abietina ALI 570 & $\mathrm{DQ} 084551$ & EU, STT & P. sylvestris & Finland \\
\hline 7 & G. abietina ALI 57I & $\mathrm{DQ} 084552$ & EU, STT & P. sylvestris & Finland \\
\hline 8 & G. abietina ALI 572 & $\overline{\mathrm{DQ} 084553}$ & EU, LTT & P. sylvestris & Finland \\
\hline 9 & G. abietina ALI 573 & $\overrightarrow{\mathrm{DQ} 084554}$ & EU, LTT & P. sylvestris & Finland \\
\hline 10 & G. abietina ALI 574 & $\overline{\mathrm{DQ} 084555}$ & EU, LTT & P. sylvestris & Finland \\
\hline 11 & G. abietina US 810105 & DQ084556 & EU & P. resinosa & USA \\
\hline 12 & G. abietina US 790048 & & EU & P. resinosa & USA \\
\hline 13 & G. abietina CF 910032 & DQ084557 & NA & P. banksiana & Canada \\
\hline 14 & G. abietina ALI G90 & AF548076 & EU, STT & P. contorta & Åsele, Sweden \\
\hline 15 & G. abietina ALI GI48 & AF548075 & EU, STT & P. contorta & Åsele, Sweden \\
\hline 16 & G. abietina ALI GI39 & AF548074 & EU, STT & P. contorta & Åsele, Sweden \\
\hline 17 & G. abietina ALI G3 & & EU, STT & P. sylvestris & Nattavaara, Sweden \\
\hline 18 & G. abietina ALI G4 & & EU, STT & P. sylvestris & Nattavaara, Sweden \\
\hline 19 & G. abietina ALI G6 & & EU, STT & P. sylvestris & Nattavaara, Sweden \\
\hline 20 & G. abietina ALI GI5 & & EU, STT & P. sylvestris & Nattavaara, Sweden \\
\hline 21 & G. abietina ALI GI6 & & EU, STT & P. sylvestris & Nattavaara, Sweden \\
\hline 22 & G. abietina ALI GI7 & & EU, STT & P. sylvestris & Nattavaara, Sweden \\
\hline 23 & G. abietina ALI FII3 & & EU, STT & P. contorta & Hede, Sweden \\
\hline 24 & G. abietina ALI FII4 & & EU, STT & P. contorta & Hede, Sweden \\
\hline 25 & G. abietina ALI FII6 & & EU, STT & P. contorta & Ramsele, Sweden \\
\hline 26 & G. abietina ALI FI 29 & & EU, STT & P. sylvestris & Östersund, Sweden \\
\hline 27 & G. abietina ALI FI74 & & EU, STT & P. sylvestris & Östersund, Sweden \\
\hline
\end{tabular}

To simulate the detection of G. abietina in a composite fungal background, the dilution series of G. abietina DNA was mixed with equal volumes of DNA from seven other fungi (Test 3, Table 2). In contrast to the previous two tests, this composite fungal DNA produced a visible amplification product (ca. $1.7 \mathrm{~Kb}$ in size) in all seven DNA dilution mixtures after the first round PCR with universal fungal primers (data not shown). This was due to the presence of background fungal DNA (ca. $9 \mathrm{ng}$ ) in all PCR mixes, no matter how little G. abietina DNA was present: the NS1/8 primers were compatible with all of the fungi in the mixture. Following the nested PCR, the detection limit was $0.075 \mathrm{ng}$ G. abietina DNA in the background of $9 \mathrm{ng}$ of other fungal DNA (i.e. about a hundredth of the fungal background DNA, Fig. 4a, b Test 3). This is a pronounced decrease in detection sensitivity compared to Tests 1 and 2. In contrast, the detection sensitivity of the nested PCR using the specific primers in both PCR steps was not affected by the presence of other fungal DNA, and gave the same detection sensitivity as in Test 1 and 2 (Fig. 4c Test 3).

\section{Detection of G. abietina infection in Pinus contorta by nested PCR}

To test the ability of the nested PCR systems to detect directly G. abietina infection in conifer trees, both brown and green needles from the infected trees of P. contorta were used for DNA isolation and PCR amplifications. All the nested PCR assays detected G. abietina in the needle samples from the infected twigs, which gave clear products of $1080 \mathrm{bp}$ and $837 \mathrm{bp}$ long with the inner primer pairs NS.Grem3/4 and NS.Grem5/6, respectively (Fig. 5). Neither the healthy P. contorta sample, nor the negative control produced any amplification product (Fig. 5). This verifies that the nested PCR product from the needle samples was amplified from $\mathrm{G}$. abietina.

\section{Discussion}

Gremmeniella abietina is widespread and causes severe damage to several conifer species. Large-scale forest epidemics have been reported from several continents $[1,6,24-26]$. The disease can spread through infected seedling nurseries. Intercontinental migration of the pathogen has also been reported as a result of international transportation of infected forest materials $[27,28]$. Rapid detection methods that can be applied directly to asymptomatic tissues would be valuable for forest disease management. Previously reported methods for the morphological, biochemical, pathogenic or genetic characterization of this fungus require its isolation in culture $[14,28-31]$. Such characterization allows the species to be subdivided into different races and types. However, host 
Table 2: Other fungal strains and conifer species included in this study.

\begin{tabular}{|c|c|c|c|}
\hline & Fungal strains & & Conifer species \\
\hline 28 & Aspergillus niger UPSC 1769 & 59 & Pinus sylvestris \\
\hline 29 & Aspergillus ochraceus UPSC 1983 & 60 & Pinus contorta \\
\hline 30 & Aspergillus flavus UPSC I768 & 61 & Pinus massoniana \\
\hline 31 & Aspergillus penicilloides ALI $23 \mathrm{I}$ & 62 & Pinus banksiana \\
\hline 32 & Aspergillus versicolor UPSC 2027 & 63 & Pinus jeffreyi \\
\hline 33 & Aspergillus silvaticus ALI 234 & 64 & Pinus strobus \\
\hline 34 & Cladosporium cladosporioides ALI 50 & 65 & Pinus koraiensis \\
\hline 35 & Chrysonilia sitophila ALI 346 & 66 & Pinus yunnanensis \\
\hline 36 & Eurotium herbariorum ALI 216 & 67 & Picea abies \\
\hline 37 & Fusarium culmorum UPSC I98I & 68 & Larix deciduas \\
\hline 38 & Microdochium nivale UPSC 3273 & 69 & Abies procera \\
\hline 39 & Mucor plumbeus UPSC 1492 & 70 & Chamaecyparis nootkatensis \\
\hline 40 & Paecilomyces variotii UPSC I65 I & 71 & Tsuga canadensis \\
\hline 41 & Penicillium commune CBS 343.5 I & 72 & Taxodium distichum \\
\hline 42 & Penicillium italicum UPSC 1577 & & \\
\hline 43 & Penicillium chrysogenum UPSC 2020 & & \\
\hline 44 & Penicillium brevicompactum ALI 319 & & \\
\hline 45 & Penicillium frequentans ALI 218 & & \\
\hline 46 & Rhizopus microsporus UPSC I758 & & \\
\hline 47 & Stachybotrys bisbyi CBS 317.72 & & \\
\hline 48 & Stachybotrys chartarum CBS 330.37 & & \\
\hline 49 & Stachybotrys dichroa CBS 182.80 & & \\
\hline 50 & Stachybotrys oenanthes CBS 252.76 & & \\
\hline 51 & Stachybotrys kampalensis CBS 388.73 & & \\
\hline 52 & Stachybotrys microspora CBS 186.79 & & \\
\hline 53 & Trichoderma reesei QM 94I4 & & \\
\hline 54 & Trichoderma viride ALI 210 & & \\
\hline 55 & Ulocladium botrytis CBS 173.82 & & \\
\hline 56 & Wallemia sebi UPSC 2502 & & \\
\hline 57 & Phacidium infestans A387 & & \\
\hline 58 & Phacidium infestans $\mathrm{A} 391$ & & \\
\hline
\end{tabular}

differentiation of the fungus is very limited and different races/types can coexist in the same geographic region and infect the same host species $[27,29,30,32,33]$. Therefore, for forest management, a general detection method for $G$. abietina, regardless of race/type, would be highly desirable. The identical 18S rDNA sequences from G. abietina of NA, EU, LTT and STT race/type isolated from different hosts indicate that, in this fungus, the sequence is conservative. Therefore, markers based on it exhibit general intraspecific applicability. A high specificity of the detection system is a prerequisite for its application in pathogen diagnosis. The specific primers developed in this study successfully detected G. abietina at species level and, thus, can function as rapid molecular markers for its identification and detection in composite fungal or plant samples without the need for isolation and cultivation. By verifying these DNA markers in a wide range of conifer species, the present study indicates that this detection system can be applied to all potential hosts, so it should be a valuable forest management tool across broad geographic regions.
Apart from the specificity, the sensitivity of a detection system is also important for early infection diagnosis, particularly in bulk samples. The sensitivity of a PCR assay depends on several factors, most importantly on the primer composition, structure and homology to the target molecule. In this study, when the three pairs of primers, NS1/8, NS.Grem3/4 and NS.Grem5/6, were tested on G. abietina DNA in single-step PCR with the same number of cycles, NS.Grem3/4 was found to be ca. 10 times more efficient than the other two pairs. The higher amplification efficiency of NS.Grem3/4 was consistent across all PCR assays (Fig. 4). Thus, careful design and selection of the primers can significantly improve the sensitivity of a PCR assay.

Nested PCR was employed in this study to improve the detection sensitivity of the pathogen in the hosts. The use of universal fungal primers in the first round PCR enriches the fungal rDNA in the plant genomic background, then, in the second round, there is selective amplification of the target pathogen. This approach is particularly attractive 

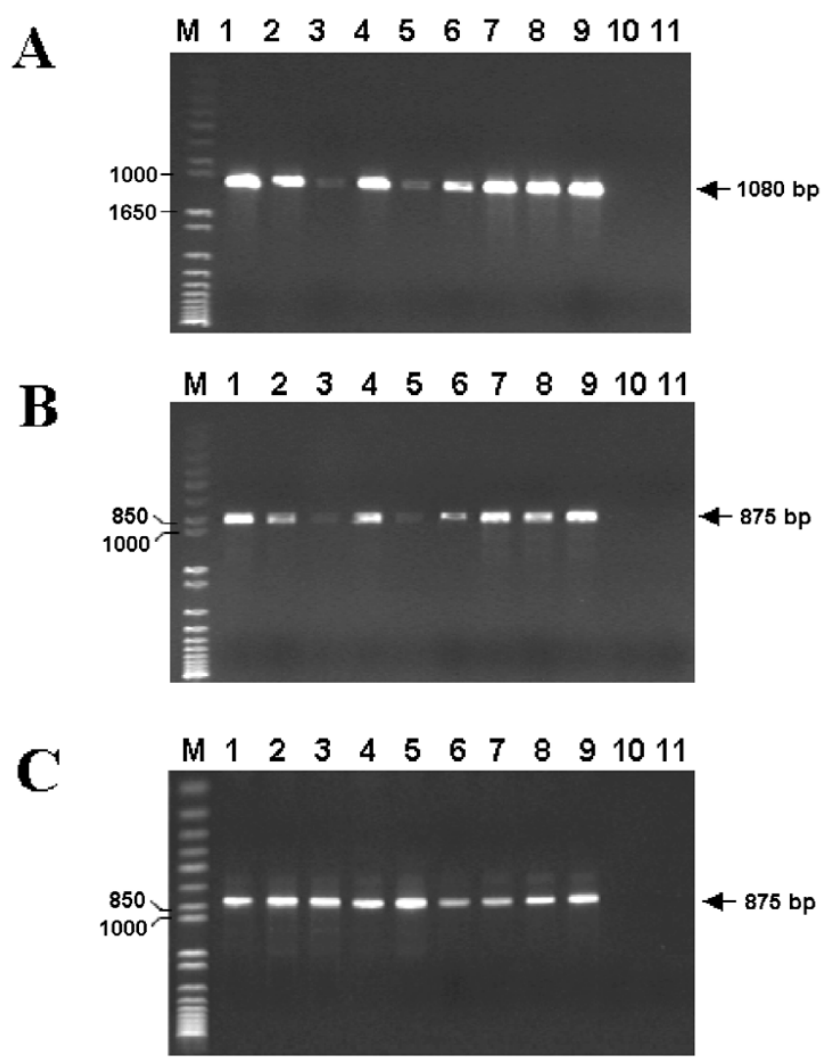

\section{Figure 5}

Detection of G. abietina in P. contorta trees. Lanes I-6: needles from six infected twigs. Lanes 7-9: positive controls using G. abietina DNA. Lane I0: healthy P. contorta. Lane I I: negative control. M: I kb Plus DNA Ladder (Invitrogen). Panels $A, B$ and $C$ show the nested PCR results of NSI/8NS.Grem3/4, NSI/8-NS.Grem5/6 and NS.Grem3/4NS.Grem5/6, respectively.

when screening for multiple fungal pathogens in minor amount of plant tissue. The nested PCR developed in this study can detect as little as a single fungal genome even in high background levels of pine DNA. The template DNA concentration and composition can influence the efficiency of nested PCR. In the presence of a high proportion of other fungal DNA the detection limit of nested PCR with outer primers being the fungal universal primers NS1/8 was significantly decreased, mainly due to primer competition in the first round PCR. Since the universal primers are compatible with all the fungi in the mixture, the very small proportion of G. abietina present $(<0.1 \%)$ would have little chance to compete for the primers. The target template was, therefore, not enriched in the first round PCR, which in turn affected the nested PCR sensitivity. This problem can be avoided by employing G. abietina-specific primers in both PCR rounds. The nested PCR based on this approach showed high detection sensi- tivity for G. abietina even in a high background of other fungal DNA. In real situations, the detection systems would usually be used on either suspected G. abietina infections or asymptomatic tissues. DNA isolated from these materials would mostly comprise the host DNA and DNA from endophytic fungi. G. abietina may or may not be the major component among the endophytic fungi. Thus, the nested PCR system using specific primers in both PCR steps would satisfy both the specificity and sensitivity requirements for diagnostic applications.

In the analysis of plant samples, extraction of sufficient fungal genomic DNA is also important since the fungal tissue is usually present at low levels relative to the amount of host tissue. If this is not achieved, the detection sensitivity may be inadequate and could result in a false negative. For large conifer trees, the stage and degree of the disease development as well as tissue sampling position would also affect the pathogen's detection. In the early stage of infection the amount and the spread of fungal mycelia is limited. Tissues from parts of the tree other than the close vicinity of the infection site may give negative detection. Thus, for large conifers multiple samples should be collected from the suspected tree for examination.

\section{Conclusion}

This study developed rapid, specific and sensitive detection systems for the conifer pathogen G. abietina. The specific markers were validated for a broad range of conifer hosts and fungi. Thus, the detection methods described here could have broad applications in forest protection and disease management programs. It should be also recognized that different race/types of G. abietina have distinct epidemiological and aetiological attributes and the ideal molecular assay should allow the user to identify not only the species but also the races and biotypes. The assay reported here could be used in combination with other race or biotype-specific assays $[12,19]$, either in a multiplex or in a sequential fashion, to better understand the distribution and disease development of different G. abietina infections.

\section{Methods}

Fungal strains, plant species and genomic DNA extraction Gremmeniella abietina was isolated from Pinus sylvestris, P. contorta, P. resinosa and P. banksiana (Table 1). Eleven isolates representing NA, EU, LTT and STT race/type were sequenced for the $18 \mathrm{~S}$ rRNA gene (Table 1). Thirty-one other fungal strains, from 15 Ascomycota genera, were included in this study to determine the specificity of the markers developed for G. abietina (Table 2). These fungi were selected taking into account their 18S rDNA-based phylogenetic relationships to G. abietina [34], so both closely related and divergent groups were included. Pure 
Table 3: DNA dilutions and mixtures used in the sensitivity test. The relative abundance of $G$. abietina DNA to the other genomic background DNA is indicated in parentheses.

\begin{tabular}{|c|c|c|c|}
\hline & Test I G. abietina & Test 2 G. abietina $+P$. contorta & Test $3 \mathrm{G}$. abietina +7 fungi mix \\
\hline \multicolumn{4}{|c|}{ Sample } \\
\hline 1 & $5 \times 10^{-1} \mathrm{ng} / \mu \mathrm{l}$ & $5 \times 10^{-1} \mathrm{ng} / \mu \mathrm{l}+4 \mathrm{ng} / \mu \mathrm{l}(\mathrm{I}: 8)$ & $5 \times 10^{-1} \mathrm{ng} / \mu \mathrm{l}+6 \mathrm{ng} / \mu \mathrm{l}(\mathrm{l}: 12)$ \\
\hline 2 & $5 \times 10^{-2} \mathrm{ng} / \mu \mathrm{l}$ & $5 \times 10^{-2} \mathrm{ng} / \mu \mathrm{l}+4 \mathrm{ng} / \mu \mathrm{l}(\mathrm{l}: 80)$ & $5 \times 10^{-2} \mathrm{ng} / \mu \mathrm{l}+6 \mathrm{ng} / \mu \mathrm{l}(\mathrm{I}: 120)$ \\
\hline 3 & $5 \times 10^{-3} \mathrm{ng} / \mu \mathrm{l}$ & $5 \times 10^{-3} \mathrm{ng} / \mu \mathrm{l}+4 \mathrm{ng} / \mu \mathrm{l}(\mathrm{l}: 800)$ & $5 \times 10^{-3} \mathrm{ng} / \mu \mathrm{l}+6 \mathrm{ng} / \mu \mathrm{l}(\mathrm{I}: 1200)$ \\
\hline 4 & $5 \times 10^{-4} \mathrm{ng} / \mu \mathrm{l}$ & $5 \times 10^{-4} \mathrm{ng} / \mu \mathrm{l}+4 \mathrm{ng} / \mu \mathrm{l}(\mathrm{I}: 8000)$ & $5 \times 10^{-4} \mathrm{ng} / \mu \mathrm{l}+6 \mathrm{ng} / \mu \mathrm{l}(\mathrm{I}: 12000)$ \\
\hline 5 & $5 \times 10^{-5} \mathrm{ng} / \mu \mathrm{l}$ & $5 \times 10^{-5} \mathrm{ng} / \mu \mathrm{l}+4 \mathrm{ng} / \mu \mathrm{l}(\mathrm{l}: 80000)$ & $5 \times 10^{-5} \mathrm{ng} / \mu \mathrm{l}+6 \mathrm{ng} / \mu \mathrm{l}(\mathrm{l}: 120000)$ \\
\hline 6 & $5 \times 10^{-6} \mathrm{ng} / \mu \mathrm{l}$ & $5 \times 10^{-6} \mathrm{ng} / \mu \mathrm{l}+4 \mathrm{ng} / \mu \mathrm{l}(\mathrm{I}: 800000)$ & $\begin{array}{c}5 \times 10^{-6} \mathrm{ng} / \mu \mathrm{l}+6 \mathrm{ng} / \mu \mathrm{l} \\
(1: 1200000)\end{array}$ \\
\hline \multirow[t]{2}{*}{7} & $5 \times 10^{-7} \mathrm{ng} / \mu \mathrm{l}$ & $\begin{array}{c}5 \times 10^{-7} \mathrm{ng} / \mu \mathrm{l}+4 \mathrm{ng} / \mu \mathrm{l} \\
(1: 8000000)\end{array}$ & $\begin{array}{c}5 \times 10^{-7} \mathrm{ng} / \mu \mathrm{l}+6 \mathrm{ng} / \mu \mathrm{l} \\
(\mathrm{I}: 12000000)\end{array}$ \\
\hline & $3 \mu \mathrm{l}$ in PCR & I:I vol. mix, $3 \mu \mathrm{l}$ in PCR & $\mathrm{I}: \mathrm{I}$ vol. mix, $3 \mu \mathrm{l}$ in PCR \\
\hline
\end{tabular}

cultures of these fungi were used for DNA isolation. Phylogenetic study has shown that species in the Helotiales and Rhytismatales are closely related to Gremmeniella [35] and many of them are plant pathogenies. We could not include them in the tests due to the lack of fungal material. However, $18 \mathrm{~S}$ rDNA sequences of 40 species of Helotiales and Rhytismatales were downloaded from GenBank for sequence analysis.

Fourteen conifer species from three families (Pinaceae, Cupressaceae and Taxodiaceae) were selected to represent the potential range of hosts (Table 2). Since pines are most susceptible to this pathogen, eight pine species native to Asia, Europe and North America were selected, representing the two Pinus subgenera: Pinus and Strobus. Three other reported hosts of G. abietina were also included: Picea, Abies and Larix. Seeds of each species were germinated on sterilized Petri dish for 2 - 3 weeks and used for DNA isolation. Twigs from six infected trees of $P$. contorta were collected in the forest of northern Sweden. From these, both brown and green needles were collected for DNA isolation.

The fungal genomic DNAs were isolated from a pure culture of each strain following the procedure described by Wu et al [36]. The genomic DNAs of the conifer species were isolated using a DNeasy ${ }^{\oplus}$ Plant Mini Kit (Qiagen, Germany). The pine needles were thoroughly homogenized, as follows. Two ceramic beads, $4 \mathrm{~mm}$ in diameter (Iuchi, Japan) and $350 \mathrm{mg}$ of $0.5 \mathrm{~mm}$ zirconia-silica beads (Biospec Products, Inc., Bartlesville, OK, USA), were placed in a $2-\mathrm{ml}$ microtube containing $100 \mathrm{mg}$ pine needles. The tubes were placed in a Mini-Bead Beater (Biospec Products, Inc.) and homogenized for $2 \mathrm{~min}$ at the maximum speed. The rest of the isolation procedure followed that suggested by the manufacturer of the DNeasy Plant Mini Kit (Qiagen, Germany).

\section{Specific primers}

The 11 G. abietina isolates sequenced for the $18 \mathrm{~S}$ rRNA gene produced identical sequences, with one exception of a single substitution among them (GenBank accession numbers see Table 1). This sequence was aligned with the $18 \mathrm{~S}$ rRNA sequences of the 31 other fungal strains listed in Table 2 as well as 40 Helotiales and Rhytismatales fungi accessed from GenBank (data not shown). Unique sequence patterns to G. abietina were utilized to design specific primers. Two pairs of primers, NS.Grem $3 / 4$ and NS.Grem5/6 (Fig. 1), were designed for G. abietina. To ensure the specificity of the PCR assay, these primers were first screened against sequences in GenBank using the BLAST function to examine their possible homology to other fungi. The "Search for short, nearly exact matches" program was used. These primers showed $>20 \%$ mismatches to any other fungal sequences in GenBank including the $4018 \mathrm{~S}$ rDNA sequences of Helotiales and Rhytismatales. Under stringent PCR conditions, a $>20 \%$ mismatch between the target molecule and the primer would not result in specific amplification.

\section{Nested PCR}

To increase the detection sensitivity, two nested PCR systems were developed. One approach used the $18 \mathrm{~S}$ rDNAbased universal fungal primers NS1 and NS8 [37] as outer primers in the first round PCR. Amplification was performed in a volume of $25 \mu \mathrm{l}$ containing $1-5 \mathrm{ng}$ of template DNA, $10 \mathrm{pmol}$ of each primer, $0.75 \mathrm{U}$ of Taq DNA polymerase (Invitrogen Life Technologies, USA), $200 \mu \mathrm{M}$ of each dNTP (Amersham Pharmacia Biotech, USA), and $1.5 \mathrm{mM} \mathrm{MgCl}_{2}$. PCR conditions were optimized to comprise an initial denaturation of $3 \mathrm{~min}$ at $95^{\circ} \mathrm{C}$, followed by 36 cycles of $94^{\circ} \mathrm{C}$ for $30 \mathrm{~s}, 45^{\circ} \mathrm{C}$ for $45 \mathrm{~s}$ and $72^{\circ} \mathrm{C}$ for $90 \mathrm{~s}$, followed by a final extension of $10 \mathrm{~min}$ at $72^{\circ} \mathrm{C}$. A 1 $\mu \mathrm{l}$ aliquot of the first round PCR product was used as the template in the second round, using the G. abietina-spe- 
cific primers NS.Grem3/4 or NS.Grem5/6. The PCR conditions for these two specific primer pairs were similar to the NS1/8 amplification, except that the PCR cycles were decreased to 25 in the second round PCR and the annealing temperatures were $60^{\circ} \mathrm{C}$ and $56^{\circ} \mathrm{C}$ for NS.Grem $3 / 4$ and NS.Grem5/6, respectively. In another approach, G. abietina-specific primer pair NS.Grem3/4 was used in the first round PCR and NS.Grem5/6 in the second round. The PCR procedure is the same as that described above. A negative control was included in all PCR runs. PCR products $(3 \mu \mathrm{l})$ were analyzed by electrophoresis on $1.4 \%$ agarose gels in $1 \times$ TAE buffer. The gels were stained with ethidium bromide and visualized under UV light using a Gel Doc 2000 fluorescent gel documentation system (BioRad, USA).

\section{Sensitivity evaluation}

To determine the detection limit of the nested PCR, three DNA dilution series were created and subjected to the PCR analysis (Table 3). First, a 10-fold dilution series of G. abietina genomic DNA was tested (Test 1 ). The initial DNA concentration of $5 \mathrm{ng} / \mu \mathrm{l}$ was quantified using a GeneQuant Pro RNA/DNA Calculator spectrophotometer (Amersham Biosciences, Sweden). To simulate the detection of infection in a host, this dilution series of G. abietina DNA was mixed with genomic DNA (4 ng/ $\mu \mathrm{l})$ of P. contorta in equal volume (Test 2). A $3 \mu \mathrm{l}$ aliquot of this mixture at each dilution (equivalent to $1.5 \mu \mathrm{l}$ of G. abietina DNA solution plus $1.5 \mu \mathrm{l}$ of P. contorta genomic DNA) was used in each PCR (Test 2). A third test was conducted to simulate the detection of G. abietina in a mixed fungal background. For this, genomic DNAs of seven fungi Aspergillus ochraceus, Penicillium brevicompactum, Trichoderma viride, Eurotium herbariorum, Fusarium culmorum, Ulocladium botrytis and Phacidium infestans were mixed in equal quantities. The final concentration of this composite DNA was $6 \mathrm{ng} / \mu \mathrm{l}$. The $10-$ fold dilution series of G. abietina DNA was mixed with this composite fungal DNA in equal volume for PCR analyses (Test 3). A $3 \mu \mathrm{l}$ aliquot of this mixture at each dilution was used in each PCR (Test 3 ). To compare the sensitivity and specificity of single-step PCR and nested PCR, the 10fold dilution series of G. abietina genomic DNA was also analyzed directly with the inner specific primers NS.Grem3/4 and NS.Grem5/6 in a single-step PCR. All the experiments conducted in this study were repeated 3 5 times.

\section{Authors' contributions}

XRW and QYZ designed and conducted the experiments. $\mathrm{PH}$, provided the Swedish G. abietina isolates, and collected and identified the infected $P$. contorta twigs. All authors read and approved the final manuscript.

\section{Acknowledgements}

We thank Prof Antti Uotila, Helsinki University, Finland, and Dr Gaston Laflamme, Laurentian Forestry Centre, Canadian Forest Service, for providing the Gremmeniella isolates from Finland and US and Canada. We also thank Prof Margareta Karlman, Dr Jesper Witzell and Andreas Bernhold, the Swedish University of Agricultural Sciences, for collecting field samples of Gremmeniella in the northernmost of Sweden. This study was supported by grants from the Swedish Research Council for Environment, Agricultural Sciences and Spatial Planning (Formas 24.0372/99), the Swedish Council for Working Life and Social Research (FAS) and the Swedish University of Agricultural Sciences.

\section{References}

I. Donaubauer E: Distribution and hosts of Scleroderris lagerbergii in Europe and North America. Eur J For Pathol 1972, 2:6-II.

2. Hellgren $M$ : Gremmeniella abietina - disease biology and genetic variation within Fennoscandia. In Department of Forest Mycology and Pathology Uppsala, Swedish University of Agricultural Sciences; 1995.

3. Skilling DD, Riemenschneider DE: Screening conifers for resistance to Gremmeniella abietina. In Proc Int Symposium Scleroderris Canker of Conifers Edited by: Manion PD. Syracuse, USA, The Hague, Martinus Nijhoff - Dr. W. Junk Publisher; 1983:189-196.

4. Barklund P, Rowe J: Gremmeniella abietina (Scleroderris lagerbergii), a primary parasite in a Norway spruce dieback. Eur J For Path 1981, I 1:97-108.

5. Hellgren M, Barklund P: Studies of the life-cycle of Gremmeniella abietina on scots pine in southern Sweden. Eur J For Path 1992, 22:300-3II.

6. Karlman M, Hansson P, Witzell J: Scleroderris canker on lodgepole pine introduced in northern Sweden. Can J For Res 1994, 24:1948-1959.

7. Lang KJ, Schütt P: Anatomische untersuchungen zur infektionsbiologie von Scleroderris lagerbergii Gr (Brunchorstia pinea (Karst.) von Höhn.). Eur J For Pathol 1974, 4: I66-I74.

8. Marosy M, Patton RF, Upper CD: A Conducive Day Concept to Explain the Effect of Low-Temperature on the Development of Scleroderris Shoot Blight. Phytopathology 1989, 79: I 293-I30 I.

9. Dorworth CE, Krywienczyk J: Comparisons among isolates of Gremmeniella abietina by means of growth rate, conidia measurement, and immunogenic reaction. Can J Bot 1975, 53:2506-2525.

10. Uotila A: Physiological and morphological variation among Finnish Gremmeniella abietina isolates. Commun Inst For Fenn 1983, I I 9: I-I2.

II. Petrini O, Toti L, Petrini LE, Heiniger U: Gremmeniella abietina and G. laricina in Europe: characterization and identification of isolates and laboratory strains by soluble protein electrophoresis. Can J Bot 1990, 68:2629-2635.

12. Hamelin RC, Ouellette GB, Bernier L: Identification of Gremmeniella abietina races with random amplified polymorphic DNA markers. Appl Environ Microbiol 1993, 59:1752-I755.

13. Lecours N, Toti L, Sieber TN, Petrini O: Pectic Enzyme Patterns as a Taxonomic Tool for the Characterization of Gremmeniella Spp Isolates. Can J Bot 1994, 72:891-896.

14. Müller MM, Uotila A: The diversity of Gremmeniella abietina var. abietina FAST-profiles. Mycol Res 1997, I 0 I:557-564.

15. Dusabenyagasani $M$, Lecours $N$, Hamelin RC: Sequence-tagged sites (STS) for studies of molecular epidemiology of scleroderris canker of conifers. Theor Appl Genet 1998, 97:789-796.

16. McCartney HA, Foster SJ, Fraaije BA, Ward E: Molecular diagnostics for fungal plant pathogens. Pest Manag Sci 2003, 59: 129-142.

17. Grote D, Olmos A, Kofoet A, Tuset JJ, Bertolini E, Cambra M: Specific and sensitive detection of Phytophthora nicotianae by simple and nested-PCR. Eur J Plant Path 2002, I 08:197-207.

18. Renker C, Heinrichs J, Kaldorf M, Buscot F: Combining nested $P C R$ and restriction digest of the internal transcribed spacer region to characterize arbuscular mycorrhizal fungi on roots from the field. Mycorrhiza 2003, 13:191-198.

19. Hamelin RC, Bourassa M, Rail J, Dusabenyagasani M, Jacobi V, Laflamme G: PCR detection of Gremmeniella abietina, the causal agent of Scleroderris canker of pine. Mycol Res 2000, 104:527-532.

20. O'Donnell K: Ribosomal DNA internal transcribed spacers are highly divergent in the phytopathogenic ascomycete Fusar- 
ium sambucinum (Gibberella pulicaris). Curr Genet 1992, 22:213-220

21. Gernandt DS, Liston A, Pinero D: Variation in the nrDNA ITS of Pinus Subsection Cembroides: Implications for Molecular Systematic Studies of Pine Species Complexes. Mol Phylogenet Evol 200I, 2I:449-467.

22. James TY, Moncalvo JM, Li S, Vilgalys R: Polymorphism at the ribosomal DNA spacers and its relation to breeding structure of the widespread mushroom Schizophyllum commune. Genetics 2001, 157:149-161.

23. Ko KS, Jung HS: Three nonorthologous ITSI types are present in a polypore fungus Trichaptum abietinum. Mol Phylogenet Evol 2002, 23: II2-122.

24. Dorworth CE: Epidemiology of Scleroderris lagerbergii in central Ontario. Can J Bot |972, 50:75|-765.

25. Skilling DD, Schneider B, Dasking D: Biology and control of scleroderris canker in North America. , USDA Forest Service, North Central Experimental Station; 1986.

26. Nevalainen S: Gremmeniella abietina in Finnish Pinus sylvestris stands in 1986-1992: a study based on the National Forest Inventory. Scand J Forest Res 1999, I 4: I I I-120.

27. Dorworth CE, Krywienczyk J, Skilling DD: New York isolates of Gremmeniella abietina (Scleroderris lagerbergii) identical in immunogenic reaction to European isolates. Plant Dis Rep 1977, 61:887-890.

28. Hamelin RC, Lecours N, Laflamme G: Molecular evidence of distinct introductions of the European race of Gremmeniella abietina into North America. Phytopathology 1998, 88:582-588.

29. Hansson $P$, Wang $X R$, Szmidt $A E$, Karlman M: RAPD variation in Gremmeniella abietina attacking Pinus sylvestris and Pinus contorta in northern Sweden. Eur J For Path 1996, 26:45-55.

30. Hantula J, Muller MM: Variation within Gremmeniella abietina in Finland and other countries as determined by Random Amplified Microsatellites (RAMS). Mycol Res 1997, I0I:169-175.

31. Wang XR: Genetic variability in the canker pathogen fungus, Gremmeniella abietina. contribution of sexual compared with asexual reproduction. Mycol Res 1997, 10 I: I 195-I 201.

32. Hansson P: Susceptibility of different provenances of Pinus sylvestris, Pinus contorta and Picea abies to Gremmeniella abietina. Eur J For Path 1998, 28:2 I-32.

33. Kaitera J, Seitamaki L, Jalkanen R: Morphological and ecological variation of Gremmeniella abietina var. abietina in Pinus sylvestris, Pinus contorta and Picea abies sapling stands in northern Finland and the Kola Peninsula. Scand J Forest Res 2000, I5:13-19.

34. Wu Z, Tsumura $Y$, Blomquist $G$, Wang XR: I8S rRNA Gene Variation among Common Airborne Fungi, and Development of Specific Oligonucleotide Probes for the Detection of Fungal Isolates. Appl Environ Microbiol 2003, 69:5389-5397.

35. Gernandt DS, Platt JL, Stone JK, Spatafora JW, Holst-Jensen A, Hamelin RC, Kohn LM: Phylogenetics of Helotiales and Rhytismatales based on partial small subunit nuclear ribosomal DNA sequences. Mycologia 200I, 93:915-933.

36. Wu Z, Wang XR, Blomquist G: Evaluation of PCR primers and PCR conditions for specific detection of common airborne fungi. J Environ Monit 2002, 4:377-382.

37. White TJ, Bruns T, Lee S, Taylor J: Amplification and direct sequencing of fungal ribosomal RNA genes for phylogenetics. In PCR protocols: A guide to methods and applications Edited by: Innis MA, Gelfand DH, Sninsky JJ and White TJ. San Diego, Academic Press; 1990:315-322.

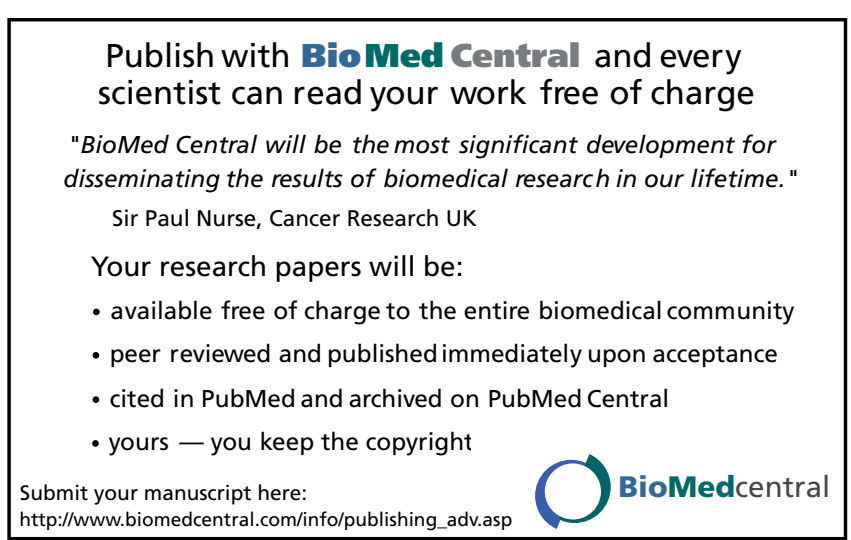

